\title{
Calcium (Ca) and Sulfur (S) for Citrus Trees ${ }^{1}$
}

\section{Mongi Zekri and Tom Obreza²}

This publication is part of a series about understanding nutrient requirements for citrus trees. For the rest of the series, visit http://edis.ifas.ufl.edu/ topic_series_citrus_tree_nutrients.

To maintain a viable citrus industry, Florida growers must consistently and economically produce large, highquality fruit crops from year to year. Efficiently producing maximum yields of high-quality fruit is difficult without understanding soil and nutrient requirements of bearing citrus trees. Most Florida citrus is grown on soils inherently low in fertility with low cation exchange capacity (CEC) and low water-holding capacity, thus soils are unable to retain sufficient quantities of available plant nutrients against leaching caused by rainfall or excessive irrigation.

Seventeen elements are considered necessary for the growth of green plants: carbon $(\mathrm{C})$, hydrogen $(\mathrm{H})$, oxygen $(\mathrm{O})$, nitrogen $(\mathrm{N})$, phosphorus $(\mathrm{P})$, potassium $(\mathrm{K})$, magnesium $(\mathrm{Mg})$, calcium $(\mathrm{Ca})$, sulfur $(\mathrm{S})$, manganese $(\mathrm{Mn})$, zinc $(\mathrm{Zn})$, iron $(\mathrm{Fe})$, copper $(\mathrm{Cu})$, boron $(\mathrm{B})$, chlorine $(\mathrm{Cl})$, molybdenum (Mo), and nickel (Ni). Plants obtain $\mathrm{C}, \mathrm{H}$, and $\mathrm{O}$ from carbon dioxide and water. The remaining elements, called the "mineral nutrients," are obtained from the soil. Mineral nutrients are classified as macronutrients and micronutrients. The term "macronutrients" refers to those elements that plants require in large amounts $(\mathrm{N}, \mathrm{P}, \mathrm{K}, \mathrm{Mg}, \mathrm{Ca}$, and $\mathrm{S})$. The term "micronutrients" applies to plant nutrients that are essential to plants but are needed only in small amounts ( $\mathrm{Mn}, \mathrm{Zn}, \mathrm{Fe}, \mathrm{Cu}, \mathrm{B}, \mathrm{Cl}, \mathrm{Mo}$, and $\mathrm{Ni}$ ). Previous EDIS articles in this series discussed the importance of $\mathrm{N}, \mathrm{P}, \mathrm{K}$, and $\mathrm{Mg}$ in relation to citrus trees. This publication focuses on the importance of calcium (Ca) and sulfur (S) nutrition.

Calcium and sulfur are sometimes called secondary nutrients. This term does not mean that these nutrients play a secondary role in citrus plant growth and development. Ca and $\mathrm{S}$ are as essential as $\mathrm{N}, \mathrm{P}, \mathrm{K}, \mathrm{Mg}$, and other nutrients for healthy plant growth. An inadequate supply of $\mathrm{Ca}$ and/or S can be a major constraint to crop production and quality.

\section{Functions and Importance of $\mathrm{Ca}$ and $\mathbf{S}$ Calcium}

Calcium is the most abundant mineral element by weight in citrus trees, accounting for approximately $1 \%$ of tree dry weight. Most Ca resides in the leaves, but fruit also contains $\mathrm{Ca}$ at a level of approximately $4.4 \mathrm{lb}$. per 100 boxes of oranges. Calcium is involved in cell division and cell elongation, is an important constituent of cell walls, and plays a major role in cell membrane integrity.

Calcium is also an important element for root development and functioning. Root growth is severely restricted in Ca-deficient plants, and the roots become more prone to bacteria and fungi infections. Calcium is required for chromosome stability and cell division. It activates several enzyme systems and neutralizes organic acids in plants. An inadequate Ca supply can reduce plant growth and fruit yield long before deficiency symptoms become evident. Soil $\mathrm{Ca}$ content is rarely low because occasional applications

1. This document is SL382, one of a series of the Department of Soil and Water Science, UF/IFAS Extension. A version of this article originally was published in Citrus Industry magazine. Original publication date: July 2013. Please visit the EDIS website at http://edis.ifas.ufl.edu.

2. Mongi Zekri, multicounty citrus UF/IFAS Extension agent; and Tom Obreza, professor and interim associate dean for Extension; UF/IFAS Extension, Gainesville, FL 32611. 
of lime (calcium carbonate, $\mathrm{CaCO}_{3}$ ) are used to control soil acidity and because $\mathrm{Ca}$ is present in irrigation water. Florida's alkaline soils have an abundance of Ca because they contain free calcium carbonate (limestone). Despite the abundance of soil $\mathrm{Ca}$, citrus trees can suffer from a range of $\mathrm{Ca}$-deficiency disorders that affect plant tissue function. For example, the "creasing" disorder in navel and Valencia oranges may be caused by Ca deficiency in the albedo of the rind.

\section{Sulfur}

The $\mathrm{S}$ concentration in a citrus tree is approximately 10 times less than the Ca concentration, and it is about equal to the $\mathrm{P}$ concentration. The uptake and assimilation of $\mathrm{S}$ and $\mathrm{N}$ by plants are strongly interrelated and depend on each other because of their mutual occurrence in amino acids and proteins. Sulfur is an essential constituent of many proteins, vitamins, and some plant hormones. As a result, protein synthesis and amino acid and chlorophyll production are retarded in S-deficient plants. Sulfur is also known to enhance the development of nodules and $\mathrm{N}$ fixation by legumes, indicating its importance in root growth and development as well as in root vigor and hardiness. Sulfur also affects carbohydrate metabolism. Sulfur is a major component of soil organic matter and becomes available to plants as organic matter decomposes. Sulfur is also present in some irrigation water sources.

Many producers often forget sulfur as a needed element and critical nutrient. The problem of S deficiency may be widespread but not known because lab analysis does not target this nutrient. In general, plant tissue analyses are important to diagnose nutritional deficiency or sufficiency of all nutrients. Unfortunately, tissue analysis has not been routinely used to check the $S$ status of citrus trees. The effects $S$ nutritional status has on yield and quality are well documented for numerous crops, but not for citrus. Sulfur controls certain diseases and insect pests in many crops and improves plant tolerance to heavy metal toxicity. Currently, sufficiency for $\mathrm{Ca}$ and $\mathrm{S}$ is defined as the optimum values in leaf tissue analysis and medium range for soil analysis.

\section{Calcium}

If soil Ca level is less than sufficient, soil application of gypsum or soluble $\mathrm{Ca}$ fertilizer should be considered. If leaf $\mathrm{Ca}$ is less than the optimum level, calcium nitrate may be applied as a foliar spray.

\section{Nutrient Behavior in Florida Soils}

\section{Calcium}

- Ca exists as solid compounds in the soil (mostly in combination with carbonate or phosphate) and in ionic forms held by the cation exchange complex.

- Solid forms of $\mathrm{Ca}$ are sparingly soluble and can reside in the soil for many years if the $\mathrm{pH}$ is not too acidic. Dissolution is more rapid at low $\mathrm{pH}$, which is the basis of the liming reaction.

- Because it is a divalent cation, Ca dominates on the cation exchange complex, limiting its mobility in soil.

\section{Sulfur}

- $90 \%$ of the $\mathrm{S}$ that occurs naturally in soils is associated with organic matter. Soil humus contains about $0.5 \%$ $\mathrm{S}$. Like $\mathrm{N}$ release, $\mathrm{S}$ release depends on organic matter quantity and decomposition rate. Organic $S$ release combined with $S$ from other sources such as rain and irrigation water may provide this nutrient to plants at a sufficient rate.

- The plant-available form of $S$ is sulfate, a negative ion, which makes it prone to leaching. Sulfate can be adsorbed by soils but adsorption usually occurs much deeper in the soil profile than the majority of plant roots.

- Calcium sulfate (gypsum) is a sparingly soluble compound applied as a long-term source of available $\mathrm{Ca}$, but it also supplies $S$ to plants.

\section{Calcium Deficiency}

A Ca deficiency in citrus is expressed as a fading of the chlorophyll along the leaf margins and between the main veins during the winter months (Figure 1). Small necrotic (dead) spots can develop in the faded areas. Calcium deficiency produces small, thickened leaves and causes loss of vigor, thinning of foliage, and decreased fruit production. Severely deficient trees can develop twig dieback and multiple bud growth of new leaves. Trees with a $\mathrm{Ca}$ deficiency produce undersized and misshapen fruit with shriveled juice vesicles (Figure 2). Fruits from Ca-deficient trees are slightly lower in juice content but higher in soluble solids and acids.

Calcium deficiency usually occurs on acidic soils where native $\mathrm{Ca}$ has leached. Continuous use of ammoniumcontaining fertilizer, particularly ammonium sulfate, accelerates Ca loss from soils. Using muriate of potash and $\mathrm{S}$ causes similar losses of soil Ca. Soil testing is a widely used method of making liming recommendations. In the long term, liming is the most effective and economic practice to 
supply Ca to crops in Ca-deficient acid soils because liming the soil neutralizes soil acidity and supplies available Ca. Calcium deficiency can also occur in highly saline soils because of the excessive sodium $(\mathrm{Na})$ concentration. Under such a situation, gypsum can correct the deficiency and reduce the deleterious effect of $\mathrm{Na}$. Short-term calcium deficiency can be addressed by foliar spraying with a water-soluble Ca source such as calcium nitrate. Calcium efficiency in crop production can also be improved by using farmland manures

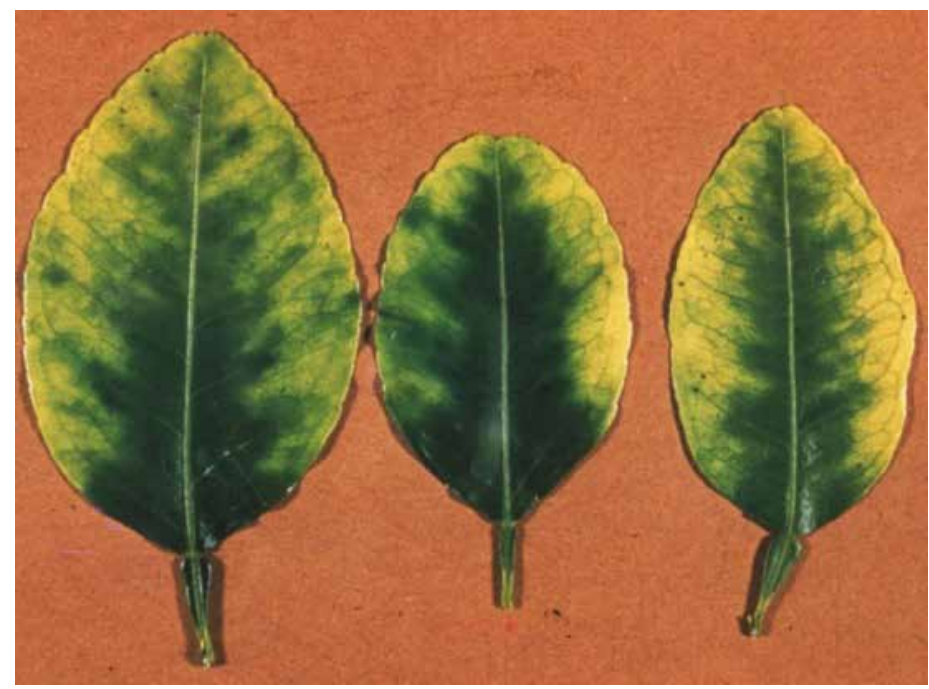

Figure 1. These leaves show calcium deficiency symptoms, including fading of the chlorophyll along the leaf margins and between the main veins during the winter months.

Credits: Dr. R. C. J. Koo

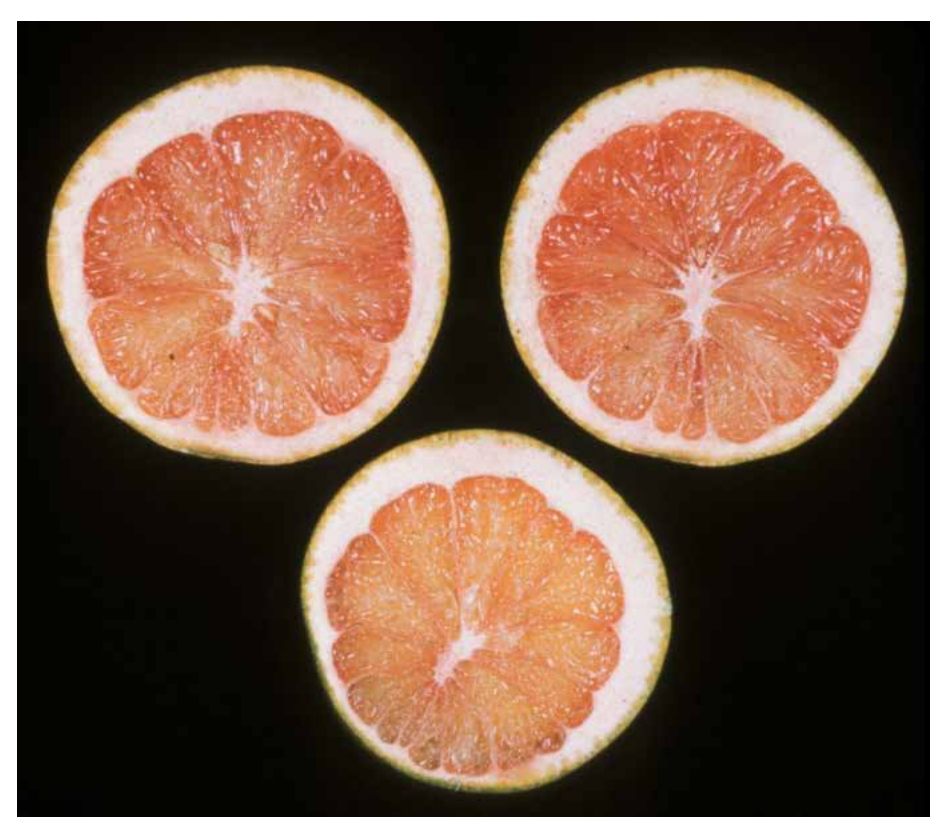

Figure 2. These fruit show calcium deficiency symptoms; they are undersized and misshapen with shriveled juice vesicles. Credits: Dr. R. C. J. Koo

\section{Sulfur Deficiency}

Because $S$ is associated with forming proteins and chlorophyll, deficiency symptoms resemble those of $\mathrm{N}$ deficiency, but the symptoms first appear on new growth (Figure 3). Such chlorosis in citrus is worse on new growth because $S$ does not move readily from old to young leaves like N. Plants are stunted and pale green to yellow in color. Visual diagnosis of $S$ deficiency is not easy to identify in citrus production. Accurate diagnosis should involve tissue analysis.

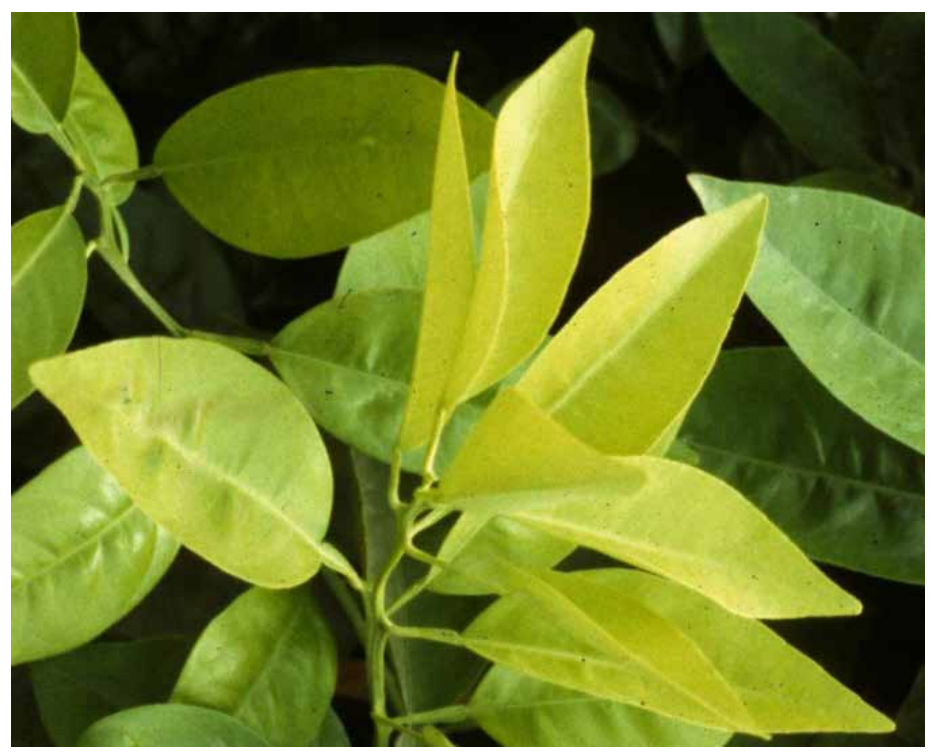

Figure 3. These leaves have sulfur deficiency symptoms because they show chlorosis (pale green to yellow in color) similar to N deficiency. $\mathrm{S}$ deficiency symptoms appear on new growth because $\mathrm{S}$ does not move readily from old to young leaves like $\mathrm{N}$.

Credits: M. Zekri

Sulfur deficiency occurs most commonly with high $\mathrm{N}$ fertilizer rates. If the supply of $\mathrm{N}$ is not supplemented with adequate $\mathrm{S}$, the $\mathrm{N}$ available for crop use may be excessive in relation to $\mathrm{S}$. Under high $\mathrm{N}$ and low $\mathrm{S}$ conditions, plant growth processes are disrupted and plants develop symptoms of S deficiency. Sometimes total growth is reduced by fertilization with $\mathrm{N}$ alone, whereas combined applications of $\mathrm{N}$ and $\mathrm{S}$ provide normal growth and yield.

Sulfur deficiencies have become more common in the past few decades with the increased use of fertilizers lacking $\mathrm{S}$, such as ammonium nitrate, potassium nitrate, urea, concentrated superphosphate, monoammonium phosphate (MAP), and diammonium phosphate (DAP). Decreased use of S-containing pesticides and fungicides may also contribute to the more common occurrence of S deficiency. Sulfur deficiency in citrus can easily be corrected by soil application of S-containing fertilizers such as ammonium sulfate, potassium sulfate, or magnesium sulfate. Applying gypsum is an inexpensive option that can also correct $\mathrm{S}$ 
deficiency and supply Ca. Using manures may also be a good management strategy to increase $S$ availability to citrus trees.

\section{Common Solid Sources for Soil Application \\ Calcium}

- Calcium carbonate (calcitic lime)

- Calcium sulfate (gypsum)

- Calcium nitrate

\section{Sulfur}

- Ammonium sulfate

- Potassium sulfate

- Potassium-magnesium sulfate

- Ordinary superphosphate

- Calcium sulfate (gypsum)

- Elemental sulfur

\section{Conclusion}

Citrus trees must have a sufficient supply of all essential plant nutrients to produce optimum fruit yields of good quality. If one or more nutrients are not supplied in adequate quantity, yield will be reduced. This effect is somewhat analogous to the saying that a wooden barrel holds no more water than its shortest stave. Growth and crop yield are limited by the element in shortest supply. An appropriate balance of nutrients in the soil is necessary to achieve optimum plant nutrition. A balanced use of plant nutrients corrects nutrient deficiencies and toxicities, improves soil fertility, increases nutrient- and water-use efficiency, enhances crop yields and fruit quality, develops tree tolerance to pests, diseases, and other stresses, and improves environmental quality. Unbalanced availability of nutrients can lead to mining soil reserves for nutrients in short supply and losing plant nutrients supplied in excess. Over- or under-fertilization is economically wasteful. Therefore, using proper rates, sources, and application methods is an important strategy to maximize nutritional efficiency and crop productivity and quality. 
Table 1. Guidelines for interpretation of orange tree leaf Ca and S (\%) analysis based on 4- to 6-month-old spring flush leaves from non-fruiting twigs

\begin{tabular}{|l|l|l|l|l|l|}
\hline & Deficient & Low & Optimum & High & Excess \\
\hline $\mathrm{Ca}$ & $<1.5$ & $1.5-2.9$ & $3.0-4.9$ & $5.0-7.0$ & $>7.0$ \\
\hline $\mathrm{S}$ & $<0.14$ & $0.14-0.19$ & $0.20-0.40$ & $0.41-0.60$ & $>0.60$ \\
\hline
\end{tabular}

Table 2. Interpretation of soil aanalysis data for $\mathrm{Ca}(\mathrm{ppm})^{*}$ using the Mehlich-1 (double-acid) extractant

\begin{tabular}{|l|l|l|}
\hline \multicolumn{1}{|c|}{ Medium } & High \\
\hline Ca & 250 & $>250$ \\
\hline *parts per million (ppm) $\times 2=$ lbs./acre
\end{tabular}

Table 3. Adjusting fertilization based on soil analysis

\begin{tabular}{|l|l|l|}
\hline & When below sufficiency & When above sufficiency \\
\hline Soil pH & Lime to $\mathrm{pH}$ 6.0. & $\begin{array}{l}\text { 1. Do nothing. } \\
\text { 2. Use acid-forming N fertilizer. } \\
\text { 3. Apply elemental sulfur. } \\
\text { 4. Change rootstocks. }\end{array}$ \\
\hline $\mathrm{Ca}$ & $\begin{array}{l}\text { 1. Check soil pH and adjust if needed. } \\
\text { 2. Check leaf Ca status. }\end{array}$ & $\begin{array}{l}\text { 1. Do nothing. } \\
\text { 2. Check leaf K and Mg status. }\end{array}$ \\
\hline
\end{tabular}

